\title{
Physicochemical Properties of a Solid Fuel from Biomass of Elephant Grass Charcoal (Pennisetum purpureum Schum.) and Recyclable PET and HDPE
}

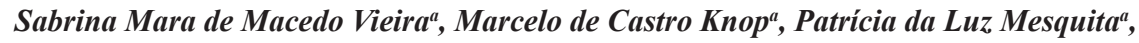 \\ Eduardo Prado Baston ${ }^{a}$ (1), Fabiano Luiz Naves ${ }^{a}$, Luiz Fernando Cappa de Oliveira ${ }^{b}$, \\ Alexandre Bôscaro França ${ }^{a *}$ (1) \\ ${ }^{a}$ Universidade Federal de São João del-Rei (UFSJ), Programa de Pós Graduação em Engenharia \\ Química, Rod. MG 443, km 05, Ouro Branco, MG, Brasil \\ ${ }^{b}$ Universidade Federal Juiz de Fora (UFJF), Núcleo de Espectroscopia e Estrutura Molecular (NEEM), \\ Campus Universitário, Juiz de Fora, MG, Brasil
}

Received: May 22, 2020; Revised: July 17, 2020; Accepted: July 19, 2020

In the search for new solid fuels that can mitigate emissions of greenhouse gases and reduce municipal solid waste, it is proposed to produce a solid fuel from elephant grass charcoal (EGC) and blend it with the following binding recyclable materials, polyethylene terephthalate (PET) and high-density polyethylene (HDPE) with the aim of increasing their mechanical strength. Immediate analysis results indicate that there was an increase in volatile material content from $21.18 \%$ to $28.02 \%$ and a reduction in fixed carbon from $65.00 \%$ to $58.40 \%$ with the addition of binding agents. The higher heating value of pure charcoal was $5924.16 \mathrm{kcal} / \mathrm{kg}$ and there was no significant alteration by adding HDPE, however, with the addition of PET, there was an average reduction of $4.82 \%$. According to the elemental analysis of charcoal, there were no significant amounts of sulphur, but silicon and potassium oxides were predominantly composed followed by aluminium, titanium, magnesium and iron according to the analysis of ashes. The addition of thermoplastic binders allowed producing pellets and it was found that those produced by using HDPE are stronger than those produced with PET.

Keywords: Charcoal, recyclable binds, briquette, solid fuel.

\section{Introduction}

Research centres and enterprises around the world are seeking alternative energy sources that can completely or partially replace fossil fuels. A consequence, biomass fuels (renewable source) have become particularly prominent. Recently, as an alternative to mineral coal, biomass-derived charcoal has been extensively studied ${ }^{1-3}$.

Biomass from elephant grass (Penisetum purpureum Schumach) presents C4 metabolism (high productivity of organic matter per hectare) which is found in abundance throughout the Brazilian territory at low management $\cos ^{4-6}$. Its heating value is about $4200 \mathrm{kcal} / \mathrm{kg}$ and it has low mechanical strength for being a non-woody vegetable, thus not being favourable for direct burning in some cases ${ }^{7,8}$.

In addition to the energy consumption of non-renewable sources, there is a widespread increase in solid waste generation, such as plastic waste, which is most often not disposed of adequately (dumps), which increases environmental impacts even further. In August 2010, was enacted in Brazil a federal law No. $12.305^{9}$, which deals with the national solid waste policy that provides for the deactivation and recovery of dumps giving rise to controlled sanitary landfills with an adaptation period until 2021. The same law also provides for the implementation of recycling, composting and other

*e-mail: alexandre.boscaro@ufsj.edu.br treatments for solid waste in general. In this context, a noble destination of the part of this waste would facilitate the implementation of this law by the states and cities.

Donato et al. ${ }^{10}$ state that charcoal produced for metallurgical purpose should have mechanical strength equal to or greater than $70 \mathrm{kgf} . \mathrm{cm}^{-2}$. Other methods of pelletizing charcoal with thermoplastic binders or other amounts of these in the blend can improve the mechanical properties of briquette ${ }^{11}$.

An ecologically friendly solution to improve charcoal pellet properties would be pelletizing it with recyclable thermoplastic binding agents PET and $\mathrm{HDPE}^{11}$. PET and HDPE are easily separable from other solid wastes and have an average higher heating value close to biomass charcoal. Thus, elephant grass charcoal has been produced according to a preset rate heating ${ }^{12}$, blended and pelletized with recyclable thermoplastic binders (PET and HDPE). The obtained material has been characterised through physicochemical tests, such as high heating value (HHV), immediate chemical analysis, thermogravimetric analysis/differential scanning calorimety (TGA/DSC) and briquette compressive strength. An electron dispersive spectroscopy (EDS) elemental analysis of charcoal and its ashes has been performed in order to find its main constituents. In addition to the aforementioned techniques, a scanning electron microscopy (SEM) analysis has been carried out to visualize the charred material morphology. 


\section{Materials and Methods}

Elephant grass charcoal has been prepared by using stems of its raw dry grass. Pyrolysis conditions selected for its production were: initial temperature $\left(T_{i}\right)$ of $25^{\circ} \mathrm{C}$; final temperature $\left(T_{f}\right)$ of $450^{\circ} \mathrm{C}$, heating rate of $10^{\circ} \mathrm{C}$. min. $^{-1}$, and $T_{f}$ has been kept for $120 \mathrm{~min}$. using a carbon steel reactor $(\varnothing=95 \mathrm{~mm} ; \mathrm{L}=130 \mathrm{~mm})$ in an inert atmosphere. After the charring process, its gravimetric yield was calculated.

In order to improve the physical and physicochemical properties of elephant grass charcoal aimed at being used as solid fuel, recyclable thermoplastics powder (PET and HDPE) have been added and mixed at mass percentages of 0 (pure), 5, 10 and $15 \%$ with powdered EGC, so that they can act as binding agents in pelletizing/briquetting. Both EGC, PET and HDE are smaller than Tyler Standard mesh 32. The obtained blends (elephant grass + binder) have been analysed by the following techniques: immediate analysis (NBR 8112); HHV (Parr instruments, model 3141); TGA/DSC (SDT 2960 Simultaneous DTA/TGA-TA Instruments); SEM/EDS (HITACHI-TM3000/BRUKER XFlash MIN SVE). Afterwards, blends were briquetted through hot compression $\left(170^{\circ} \mathrm{C} ; 80 \mathrm{kgf} / \mathrm{cm}^{2}\right)$ and then the briquettes underwent mechanical compressive strength analyses (SHIMADZU ${ }^{\circledR}$ AG-X Plus and software Trapezium X).

Sample preparation and analysis are presented in Figure 1:

\section{Results and Discussion}

The average gravimetric yield of elephant grass charcoal was $29.42 \%$. On average, the gravimetric yield of vegetal biomass processed at $450{ }^{\circ} \mathrm{C}$ generates around 21 to $33 \%$,

Table 1. Ash, volatile matter (VM), total fixed carbon (TFC) of pure charcoal and blends.

\begin{tabular}{cccc}
\hline Charcoal & Ash (\%) & VM (\%) & TFC (\%) \\
\hline Pure & 13.82 & 21.18 & 65.00 \\
\hline $5 \%$ PET & 13.44 & 24.94 & 61.62 \\
\hline $10 \%$ PET & 13.06 & 24.91 & 62.03 \\
\hline $15 \%$ PET & 12.38 & 28.02 & 59.60 \\
\hline $5 \%$ HDPE & 13.04 & 21.55 & 65.41 \\
\hline $10 \%$ HDPE & 14.36 & 27.24 & 58.40 \\
\hline $15 \%$ HDPE & 13.55 & 27.63 & 58.82 \\
\hline
\end{tabular}

depending on the age and type of plant. The obtained result is in agreement with results achieved by other researchers ${ }^{13-15}$.

The immediate analysis results of dry biomass samples are presented in Table 1, whose average moisture content of both samples was around $5.8 \%$ has been performed.

With respect to ashes, there were no significant alterations by adding the thermoplastic agents, although volatile material and fixed carbon contents have undergone significant variations concerning pure elephant grass charcoal.

According to Table 1, with the addition of PET, the pure elephant grass charcoal percentage of volatile material and fixed carbon contents ranged between $(+) 22.5 \%$ and (-) $6.4 \%$, respectively, whilst these values ranged between (+) $20.2 \%$ and (-) $6.7 \%$ with the addition of HDPE. These variations are due to the thermal decomposition of materials present in the thermoplastic polymers, since the majority of monomers present in their composition are $\mathrm{C}, \mathrm{H}$ and $\mathrm{O}$, thus presenting low content of nonvolatile contaminants.

Thermogravimetric analyses were performed in inert and oxidising atmospheres for pure charcoal and blends containing $15 \%$ of recyclable thermoplastics to verify possible events occurring in the thermal decomposition of samples. Figures 2 and 3 show the obtained results.

According to Figure 2a, the first event is observed between 30 and $115^{\circ} \mathrm{C}$ which is due to sample moisture loss. For pure charcoal at temperatures ranging from 115 to $800^{\circ} \mathrm{C}$, there is a linear mass loss of $15.42 \%$ on account of temperature increase by releasing volatile compounds and thermal decomposition of the non-charred material. On the other hand, both charcoal/polymer blends presented a marked event starting at approximately $400^{\circ} \mathrm{C}$ and ending at $490^{\circ} \mathrm{C}$ due to the thermal decomposition of polymers under study ${ }^{16-18}$.

In an oxidant atmosphere, two main events are observed. One is due to moisture loss at up to approximately $115^{\circ} \mathrm{C}$ and an exothermic one on account of the thermal degradation of EGC and EGC with PET and HDPE ${ }^{19}$. As for the charcoal blended with thermoplastics, the greatest temperature variation is shifted in over $50^{\circ} \mathrm{C}$ due to the fact that the combustion of binders occurs at higher temperatures ${ }^{18,20}$. According to Guo et al. ${ }^{20}$, PET undergoes thermo-oxidative degradation in two consecutive steps, first is relating to the degradation of the backbone and formation of a char and second is

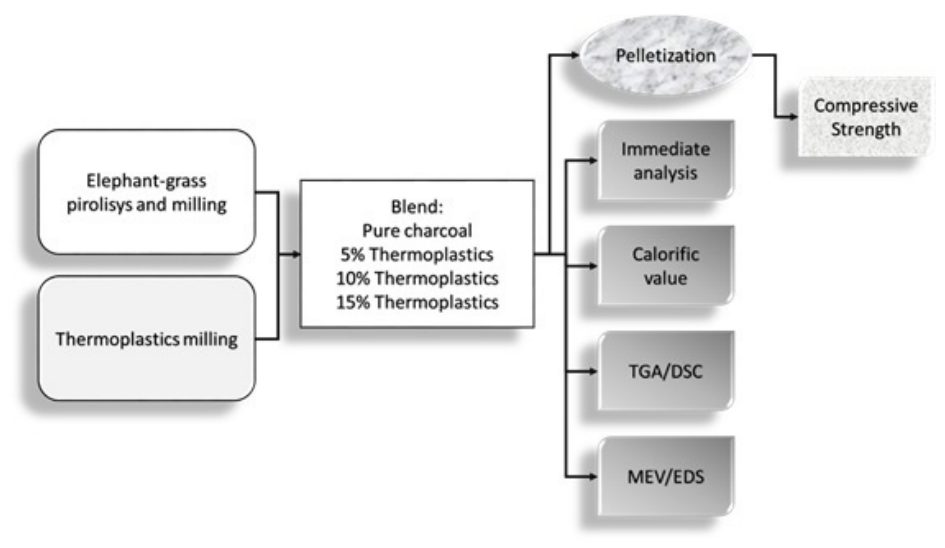

Figure 1. Schematic diagram of sample preparation and analysis. 


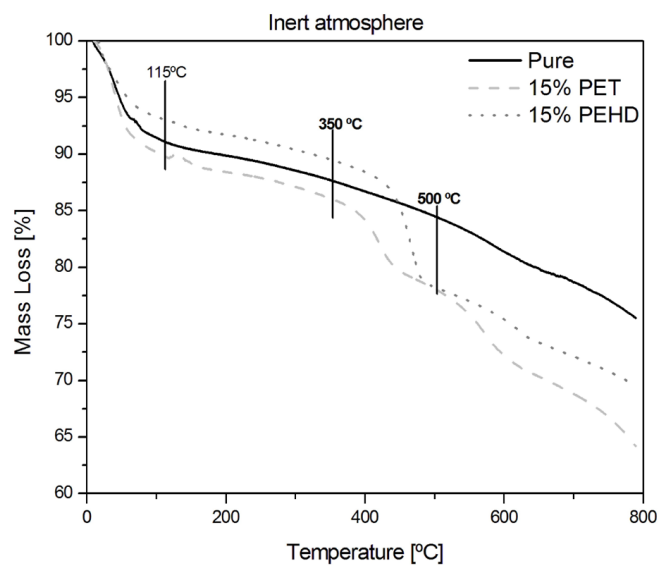

(a)

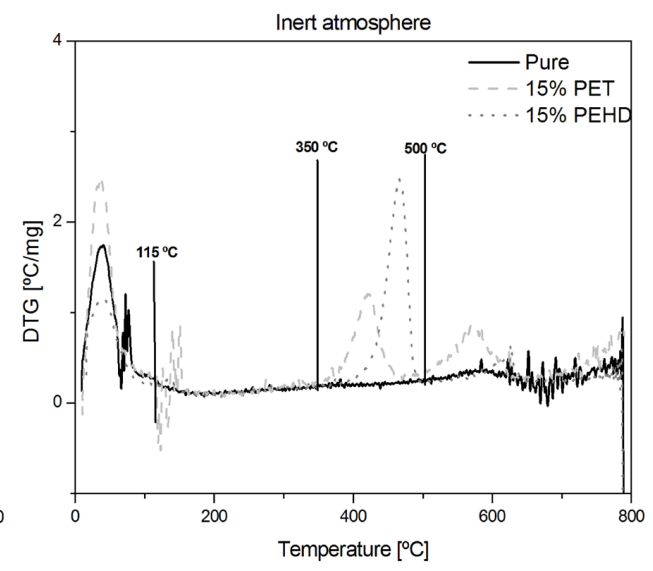

(b)

Figure 2. TG and DTG curves of samples in an inert atmosphere.
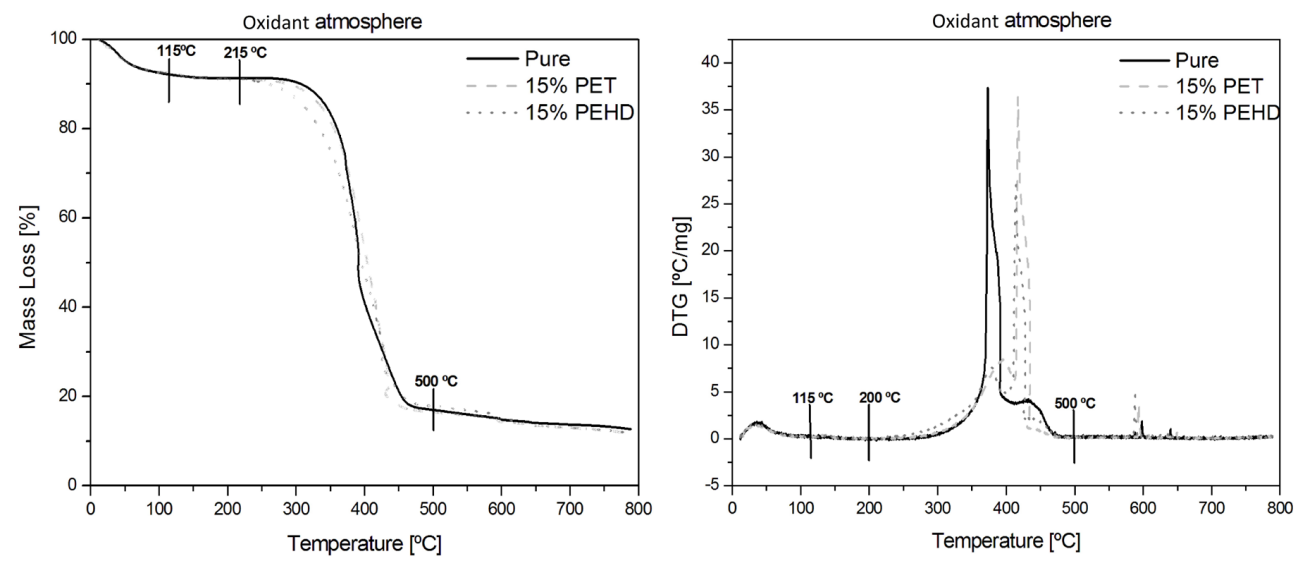

Figure 3. TG and DTG curves of samples in an oxidant atmosphere.

relating to the thermo-oxidative degradation of the char, at a temperature higher than that charcoal ${ }^{20}$.

The immediate analysis and TGA results reveal coherence in both the determination of volatile material and ash content. By disregarding the initial moisture found by the TGA in an oxidant atmosphere, the ash content obtained through this method is approximately $14 \%$, i.e. close to the one found through the immediate analysis. The volatile material content, by disregarding the initial moisture content found by the TGA in an inert atmosphere, is $28.77 \%$ for PET and $25.00 \%$ for HDPE.

Table 2 shows the variations in the high heating value of blends concerning the pure elephant grass charcoal. The results indicate that the type of thermoplastic used for briquetting/pelletizing samples exerts influence on their calorific value. On average, the high heating value of PET is approximately $5222 \mathrm{kcal} / \mathrm{kg}^{21-23}$ and $5924 \mathrm{kcal} / \mathrm{kg}$ for the pure elephant grass charcoal, thus the addition of PET tends to reduce the blend's calorific value, whilst the HDPE exerts inverse influence since its calorific value is higher than pure EGC, i.e. approximately $9543 \mathrm{kcal} / \mathrm{kg}^{23,24}$.

According to micrographs in Figures $4 \mathrm{a}$ and $4 \mathrm{~b}$, the chemical elements present in the charcoal structure and in
Table 2. Calorific value of pure elephant grass charcoal and charcoal blends with thermoplastics.

\begin{tabular}{cc}
\hline Sample & Calorific Value $\left(\mathrm{kcal}^{\mathrm{kg}}{ }^{-1}\right)$ \\
\hline Pure Charcoal & 5924.16 \\
\hline Charcoal + 5\% PET & 5706.10 \\
\hline Charcoal + 10\% PET & 5559.83 \\
\hline Charcoal + 15\% PET & 5651.67 \\
\hline Charcoal + 5\% HDPE & 5868.06 \\
\hline Charcoal + 10\% HDPE & 6051.61 \\
\hline Charcoal + 15\% HDPE & 5906.95 \\
\hline
\end{tabular}

its ashes have been identified and quantified. Light atoms with atomic weight below that of $\mathrm{C}$ could not be detected by the used technique. As observed by the EDS, charcoal is mostly composed of carbon (78\%). This result differs from that obtained by the analysis of fixed carbon content $(65 \%)$, given that EDS quantifies the carbon present in volatile matter (composed mainly of carbon, followed by hydrogen, oxygen and nitrogen). The other elements of charcoal, such as $\mathrm{K}, \mathrm{P}, \mathrm{Al}, \mathrm{Si}, \mathrm{Mg}$ and $\mathrm{Al}$ are probably as its oxides, come from salts which are essential for plant growth. In ashes, oxides of the elements cited above are 


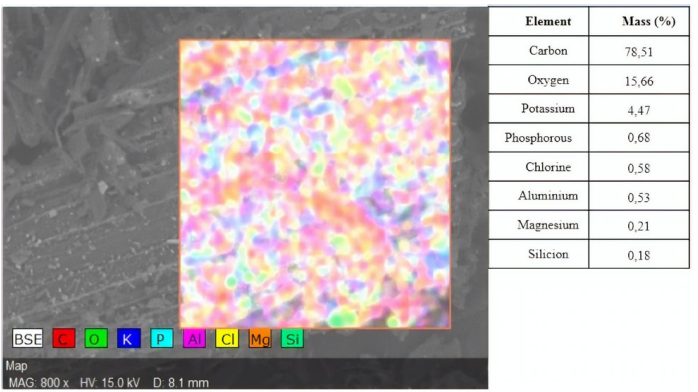

(a) Charcoal

Figure 4. SEM / EDS for elephant grass charcoal and its ash.

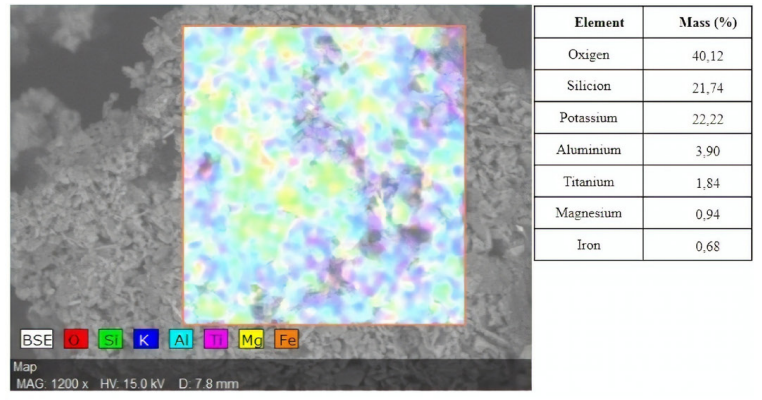

(b) Ash

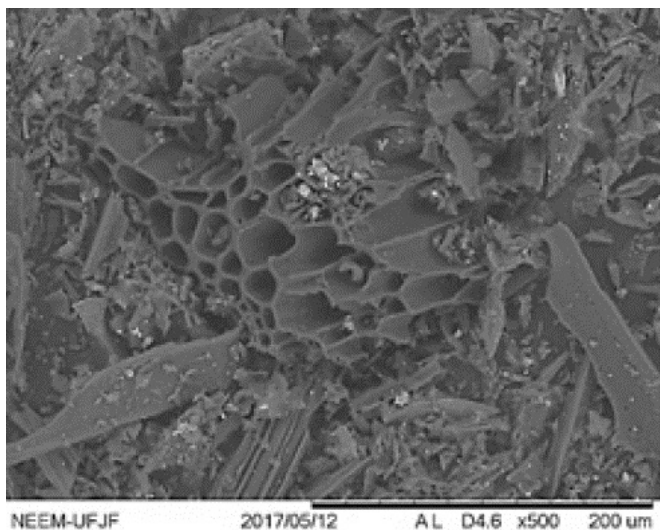

Figure 5. SEM images of elephant grass charcoal

found without C. An advantage of charcoal is its low quantity and/or absence of sulphur in its composition which, along with the fact that it is renewable, it becomes a fuel which is less harmful to the environment.

Figure 5 presents a SEM of the structure of elephant grass charcoal. The structures observed in the micrographs shown in Figure 5 are the same for all analysed charcoal samples. It is also possible to observe the formation, according to some researches ${ }^{25-27}$, of channels related to the cell structure of the plant under analysis. These structures are formed from cellulose after the loss of hydroxyl radicals by thermal dehydration of the plant. For comparison, the diameter length of the hollow carbon tube of elephant grass charcoal (non-woody cellulosic plant) $(\varnothing \cong 15.51 \mu \mathrm{m})$ is at least around two times larger than the diameter length of the hollow carbone tube of woody vegetables as Hymenaea aurea $(\varnothing \leq 8.86 \mu \mathrm{m})$ and Eucalyptus alba $(\varnothing \leq 7.42 \mu \mathrm{m})$ and five or more times larger than Mimosa Scabrella $(\varnothing \leq 3.9 \mu \mathrm{m})$ and Tabebuia capitata $(\varnothing \leq 1.0 \mu \mathrm{m})^{25}$. This characteristic results in less carbon network per volume of charcoal in non-woody vegetables like as EGC, resulting in lower mechanical resistance.

Since non-woody vegetables form charcoal with low mechanical resistance, the obtained EGC was milled and mixed with binders agents to form briquettes. Thereby, tests have been performed to determine the compressive strength limit of briquettes, whose results are presented in Table 3. According to the results shown in Table 3, an improvement

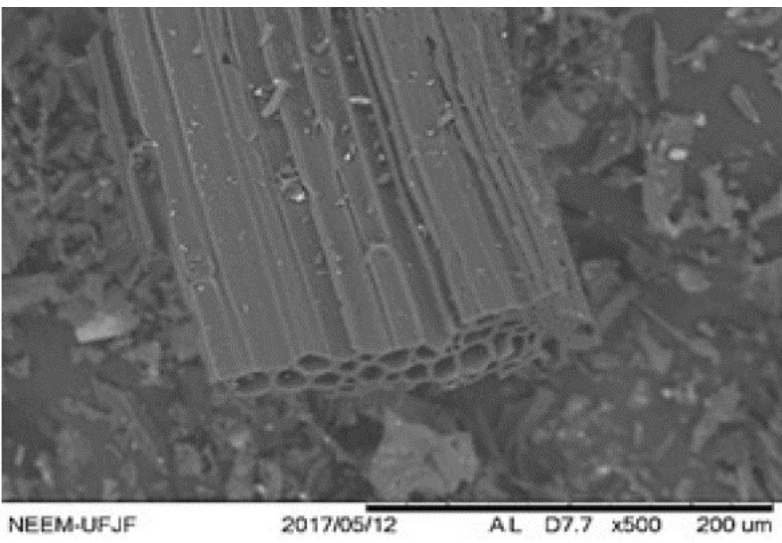

Table 3. Values of compressive strength limits for charcoal samples and briquettes formed from blends with binding agents.

\begin{tabular}{cccc}
\hline Sample & $\begin{array}{c}\text { Average } \\
\text { height } \\
(\mathrm{mm})\end{array}$ & $\begin{array}{c}\text { Average } \\
\text { diameter } \\
(\mathrm{mm})\end{array}$ & $\begin{array}{c}\text { Compressive } \\
\text { strength limit } \\
\left(\mathrm{kgf.cm}^{-2}\right)\end{array}$ \\
\hline Pure Charcoal & - & - & No binding \\
\hline Charcoal + 5\% PET & 28 & 30 & 5.16 \\
\hline Charcoal + 10\% PET & 25 & 30 & 3.42 \\
\hline Charcoal + 15\% PET & 25 & 30 & 15.30 \\
\hline Charcoal + 5\% HDPE & 23 & 30 & 15.55 \\
\hline Charcoal + 10\% HDPE & 23 & 30 & 42.04 \\
\hline Charcoal + 15\% HDPE & 19 & 30 & 59.42 \\
\hline
\end{tabular}

in mechanical strength is achieved by the addition of binders to charcoal. Charcoal fines are not able to form briquettes without binders.

The briquette produced with 15\% HDPE presented optimal results due to obtaining tensile strength or compressive strength limit of $59.42 \mathrm{kgf.cm}{ }^{-2}$, i.e. 11 times higher than that of briquette produced with 5\% PET. It was also observed that the higher the percentage of binder being used in the blend is, the greater the mechanical strength becomes.

As a comparison, Donato et al. ${ }^{10}$ obtained pellets of charcoal fines with different binders, in their work the compressive strength was not higher than $0.89 \mathrm{kgf} . \mathrm{cm}^{-2}$ while the high heating value was $6944.5 \mathrm{kcal} / \mathrm{kg}$. Robinson et al..$^{28}$ found a gross calorific value to wood pellet and wood-PET pellet as $4397.15 \mathrm{kcal} / \mathrm{kg}$ and $4767.36 \mathrm{kcal} / \mathrm{kg}$, respectively. 


\section{Conclusion}

The immediate analysis data show a fixed carbon content of $65 \%$ for charcoal and that the binder addition reduced it, in addition to an average ash content of $13 \%$. Ashes obtained from elephant grass charcoal and its blends with the binding materials present a typical composition of this raw material. No traces of sulphur were found, which makes it a solid fuel with reduced environmental impact. According to heating value data (5559 to $6051 \mathrm{kcal} / \mathrm{kg}$ ), it is possible to affirm that the material produced can be used as fuel and that the PET binder reduces the heating value of pellets. On the other hand, HDPE increases their heating value. The mechanical strength of obtained pellets increased by the addition of thermoplastic binders, and HDPE is the one that achieved the greatest compressive strength $\left(59.42 \mathrm{kgf.cm}{ }^{-2}\right)$. Based on the data obtained in this work, it is possible to try to implement a continuous briquetting process using a screw extruder and test different pressures and temperatures for briquetting. New recycled binding agents such as polystyrene, polypropylene and others can also be tested.

\section{Acknowledgements}

The authors are thankful to FAPEMIG for the master's degree scholarships and to Prof. José Antônio da Silva (UFSJ) for the calorific value analysis.

\section{References}

1. Elleuch A, Halouani K, Li Y. Investigation of chemical and electrochemical reactions mechanisms in a direct carbon fuel cell using olive wood charcoal as sustainable fuel. J Power Sources. 2015;281:350-61.

2. Purwanto H, Zakiyuddin AM, Rozhan AN, Mohamad AS, Saller HM. Effect of charcoal derived from oil palm empty fruit bunch on the sinter characteristics of low grade iron ore. J Clean Prod. 2018;200:954-9.

3. Adrados A, Lopez-Urionabarrenechea A, Acha A, Solar J, Caballero BM, de Marco I. Hydrogen rich reducing gases generation in the production of charcoal from woody biomass carbonization. Energy Convers Manage. 2017;148:352-9.

4. Quesada DM, Boddey RM, Reis VM, Urguiara S. Parâmetros qualitativos de genótipos de Capim Elefante (PennisetumpurpureumSchum.) estudados para a produção de energia através da biomassa. Seropédica, RJ: Embrapa; 2004. pp. 1-4. (Circular Técnica; 8).

5. Basso V, Machado JC, Lédo FJS, Carneiro JC, Fontana RC, Dillon AJP, et al. Different elephant grass (Pennisetum purpureum) accessions as substrates for enzyme production for the hydrolysis of lignocellulosic materials. Biomass Bioenergy. 2014;71:155-61.

6. Samson R, Mani S, Boddey RM, Sokhansanj S, Quesada $\mathrm{DM}$, Urquiaga $\mathrm{S}$, et al. The potential of $\mathrm{C} 4$ perennial grasses for developing a global bioheat industry. Crit Rev Plant Sci. 2005;24:461-95.

7. Tavares SRL, Santos TE. Uso de diferentes fontes de biomassa vegetal para produção de biocombustíveis sólidos. Holos. 2013;5:19-27.

8. Zanetti JB. Identificação de Genótipos de Capim-Elefante (Pennisetum purpureum Schumach) de Alta produção de biomassa com qualidade para fins energéticos. [dissertation]. Seropédica, RJ: Universidade Federal do Rio de Janeiro; 2010.

9. Brasil. Lei $\mathrm{n}^{\circ} 12.305$, de 2 de agosto de 2010. Institui a Política Nacional de Resíduos Sólidos; altera a Lei no 9.605, de 12 de fevereiro de 1998; e dá outras providênciasde. Diário Oficial da União; Brasília; 2 agosto 2010.

10. Donato DB, da Silva CMS, Magalhães MA, Junior CAA, Carneiro ACO, Vital BR. Propriedades de briquetes obtidos de finos de carvão vegetal. Ciênc Madeira. 2015;6(2):207-11.

11. Garrido MA, Conesa JA, Garcia MD. Characterization and Production of Fuel Briquettes made from biomass and plastic wastes. Energies. 2017;10:850.

12. Vieira SMM. Produção de carvão vegetal para fins energéticos a partir da carbonização de Capim Elefante (Pennisetum purpureum Schum.) e sua briquetagem com diferentes agentes aglutinantes. [dissertation]. Ouro Branco: Universidade Federal de São João del-Rei; 2017.

13. Pereira BLC, Carneiro ACO, Carvalho AMML, Colodette JL, Oliveira AC, Fontes MPF. Influence of chemical composition of eucalyptus wood on gravimetric yield and charcoal properties. BioResources. 2013;8(3):4574-92.

14. Soares VC. Comportamento térmico químico e físico da madeira e do carvão de Eucalyptusurophylla X Eucalyptusgrandis em diferentes idades. [thesis]. Lavras: Universidade Federal de Lavras; 2011

15. Anastasakis K, Kitisiou I, Jong W. Fast devolatilization characteristics of 'low cost' biomass fuels, wood and reed. Potential feedstock for gasification. Fuel Processisng Thecnology, 2016;142:157-166

16. Yogesh CR, Parimal AP. Thermal degradation of rice-bran with high density polyethylene: A kinetic study. Korean J Chem Eng. 2011;28(3):788-92.

17. Raid B, Mohammad MF. Thermo-Gravimetric Stability of High DensityPolyethylene composite filled with olive shell flour. Am J Pol Sci. 2015;5(3):65-74.

18. Jeffery DP, Sergey V, Charles AW. Kinetics of the thermal and Thermo-Oxidative Degradation of Polystyrene, Polyethylene and Poly(propylene). Macromol Chem Phys. 2001;202:775-84

19. Morais LC, Maia AAD, Guandique MEG, Rosa AH. Pyrolysis and combustion of sugarcane bagasse. J Therm Anal Calorim. 2017;129:1813-22.

20. Guo W, Su Y, Jhang J, Lai W, Chen C. Cheng, Effects of introducing bamboo charcoal on thermo-physical properties and combustion behavior of poly (ethylene terephthalate). J Polym Res. 2011;18:1417-24.

21. Martin-Gullón I, Esperanza M, Front R, Kinetic for the pyrolysis and combustion of poly(ethylene terephthalate) (PET). J Anal Appl Pyrolysis. 2001;58-59:635-50.

22. Çepeliogullar Ö, Pütün AE. Products characterization study of a slow pyrolysis of biomass-plastic mixtures in a fixed-bed reactor. J Anal Appl Pyrolysis. 2014;110:363-74.

23. Kannan P, Shoaibi AA, Srinivasakannan C. Energy recovery from co-gasification of waste polyethylene and polyethylene terephthalate blends. Comput Fluids. 2013;88:38-42.

24. Zevenhoven R, Karlsson M, Hupa MM, Frankenhaeuser M. Combustion and gasification porperties of plastic particles. J Air Waste Manag Assoc. 1997;47:861-70.

25. Muñiz GIB, Carneiro ME, Nisgoski S, Ramirez MGL, Magalhães WLE. SEM and NIR characterization of four forest species charcoal. Wood Sci Technol. 2013;47:815-23.

26. Kumar V, Tyagi PK. Potential application of multi-walled carbon nanotubes/activated carbon/bamboo charcoal for efficient alcohol sensing. J Alloys Compd. 2018;767:215-22.

27. Hobley E, Willgoose GR, Frisia S. Jacobsen, Vertical distribution of charcoal in a sandy soil: evidence from DRIFT spectra and field emission scanning electron microscopy. Eur J Soil Sci. 2014;65:751-62.

28. Robinson T, Bronson B, Gogolek P, Mehrani P. Comparison of the air-blown bubbling fluidized bed gasification of wood and wood-PET pellets. Fuel. 2016;178:263-71. 